\title{
Functions of Cost Management Systems in Modern Organizational Management
}

\author{
Marina Evgenievna Ordynskaya*, Tatyana Alexandrovna Silina, Lala Eldarovna Divina, Irina \\ Fedorovna Tausova, Saida Aslanbievna Bagova
}

Adyghe State University, 208 Pervomayskaya Street, Maykop, 385000, Russian Federation

Received March 17, 2021; Revised May 28, 2021; Accepted June 15, 2021

\section{Cite This Paper in the following Citation Styles}

(a): [1] Marina Evgenievna Ordynskaya, Tatyana Silina, Lala Eldarovna Divina, Irina Fedorovna Tausova, Saida Aslanbievna Bagova, "Functions of Cost Management Systems in Modern Organizational Management," Universal Journal of Accounting and Finance, Vol. 9, No. 3, pp. 498 - 505, 2021. DOI: 10.13189/ujaf.2021.090324.

(b): Marina Evgenievna Ordynskaya, Tatyana Silina, Lala Eldarovna Divina, Irina Fedorovna Tausova, Saida Aslanbievna Bagova (2021). Functions of Cost Management Systems in Modern Organizational Management. Universal Journal of Accounting and Finance, 9(3), 498 - 505. DOI: 10.13189/ujaf.2021.090324.

Copyright $\bigcirc 2021$ by authors, all rights reserved. Authors agree that this article remains permanently open access under the terms of the Creative Commons Attribution License 4.0 International License

\begin{abstract}
The purpose of the study is to analyze the functions of a cost management system in modern organizational management. Based on general scientific research methods and an expert survey, the key functions of cost management are defined. The authors justify the feasibility of developing a cost management system with the determination of cost management functions. The key approaches to cost analysis are formulated. It is important to ensure stable connections between the elements of the management system at the management level of the business hierarchy during the implementation of cost management functions. Moreover, one must build a mutual cost regulation mechanism at the stages of planning, organization, technological process development, and production, i.e. during the creation of the entire business process. There is a need for coordinated work by all the structural departments at the enterprise with strong horizontal and vertical logistical connections and established responsibility centers during the development of the general management system that the cost management system should be integrated into it. The tried and tested communication plan for information transmission and coordination between structural units at an enterprise determines the efficiency of the management and control systems aimed at maximum impact from management at the executive level when management decisions are made. The practical significance of analyzing the functions of cost management systems in a modern organization management system consists in increasing the
\end{abstract}

efficiency of management decisions made based on the data from the analytical assessment of the costs of the enterprise. The theoretical significance lies in the chance to use the study results during the development of a general organization management system.

Keywords Cost, Organization Management System, Responsibility Centers, Functions of Management System, Automated Cost Management System, Management System Efficiency

\section{Introduction}

In day-to-day operations, all business entities spend certain resources on production, management, sales, purchasing, and the like. The amount of costs largely determines the competitiveness and profitability of products, as well as the efficiency of production and economic activities of economic entities in the end. In today's conditions, some of the important issues of the enterprise management system are the assessment of the cost level and the search for ways to reduce them and the study of sales markets for products (goods, services) to obtain the maximum income.

Therefore, the stability and development of any business entity in a competitive market will depend, first of all, on the creation of an effective cost management 
system (CMS). The lack of relevant practical developments concerning the CMS and the formation of its improved model indicate the need to deepen the theoretical, methodological, and practical foundations of this problem. The first is associated with a variety of different types of costs, which contributes to their classification for generalization, to optimize the formulation of management accounting at enterprises. The second problem lies in the change in the composition of the costs themselves. The third problem lies in the impossibility of accurately measuring the composition of costs, which affects the implementation of accounting operations and, accordingly, the financial result of the enterprise as a whole.

To form a CMS, one must determine the structure of this system which should contain components (elements) interacting with each other following the tasks set. Because of this, cost management requires detailed study and improvement since cost management serves as a guarantee of the efficiency of making management decisions based on the analytical assessment of the costs of the enterprise. Therefore, one must determine the main functions of the CMS in the modern organization management system.

\section{Literature Review}

A lot of specialists have studied the CMS of an organization.

A significant contribution to the development of theoretical aspects of cost accounting and calculating the prime cost of products (works, services) was made in works [1-4]. Various aspects of cost management automation are considered in the works [5-8].

Work [9] is devoted to the direction of cost management to improve the efficiency of economic activities of an enterprise through the relationship of strategic goals, factors, resources, and results. Work [10] indicates that "the information base for decision-making is the analysis of strategic elements of cost management and the interpretation of modern cost accounting systems". However, this work does not disclose the practical aspects of the formation and organization of the CMS, and the described methods do not have actual evidence of their application. The authors of [11] considered the methodology of searching for competitive advantages and general strategy, as well as the practice of lean accounting and cost management. However, the issues of cost formation were not considered. An alternative solution to the cost management problem is presented in [12]. This paper defines that the essence of cost management as "creating a logical connection between concepts and procedures and how they are used in practice by business organizations".

Practical experience of interaction of cost management with the product development process shown in [13] is interesting for application. However, in these works, the influence of cost accounting methods on the efficiency of economic activity is not substantiated. The work [14] emphasizes the importance of "cost management as an interactive process of analysis, planning, organization, accounting, and control, which provides for the regular correlation of significant accounting information with the firm's strategy for making tactical and strategic management decisions". However, the author found that none of the existing cost management methods applied separately can fully ensure the implementation of accounting and management functions necessary to organize an effective CMS.

As for the definition of "cost management", in most studies, it is characterized as a process of cost formation and rational use of resources (Table 1).

Therefore, researchers approach this definition in a process-based or systematic way.

We believe that each of the interpretations has a deep meaning. However, regardless of the above definitions, costs cannot be considered independently from such indicators as profit and income since efficient cost management provides conditions for businesses to achieve positive results. Thus, cost management can be characterized as a system of interrelated elements (subject, object, tasks, tools, methods) that has the corresponding functional aspects (organization, planning, accounting, control, analysis, regulation).

Research hypothesis: the efficiency of the implementation and operation of CMS depends on adequately defined cost management functions (CMFs), which further leads to cost control and cost reduction. 
Table 1. Interpreting the notion of "cost management"

\begin{tabular}{|c|c|}
\hline Author, source & Cost management is \\
\hline R. Cooper, R. Slagmulder [15] & the process of target costing and facilitation of cost reduction \\
\hline G. Favato, R. Mills [16] & the process of targeted formation of the optimal level of costs for the enterprise \\
\hline S. Aluko et al. [17] & $\begin{array}{l}\text { the development and implementation of managerial actions for the formation and regulation of enterprise } \\
\text { costs according to strategic and current goals }\end{array}$ \\
\hline R.L. Tichacek [18] & $\begin{array}{c}\text { the dynamic management process of regulating the rational use of material, labor, financial, and natural } \\
\text { resources and conditions of the organization's business to ensure competitive advantages, aimed at } \\
\text { achieving the best economic result of the activities of the enterprise }\end{array}$ \\
\hline A. Kumar [19] & $\begin{array}{l}\text { the system of management decisions on the formation and regulation of costs, ensuring the efficient use of } \\
\text { resources and capital of the enterprise in various types of its activities in accordance with strategic and } \\
\text { current development goals }\end{array}$ \\
\hline A. Garg et al. [20] & $\begin{array}{c}\text { activities associated with an analytical assessment of the formation of costs by types of activities and } \\
\text { products (goods, works, services), efficiency of use, and the search for saving resources to determine the } \\
\text { so-called "effect", profitability, and competitiveness }\end{array}$ \\
\hline
\end{tabular}

Research objectives:

- based on the analysis of scientific literature, to define the concept of "cost management";

- based on an expert survey, to indicate the main CMF with the construction of a generalized system of CMF of the organization;

- to substantiate the feasibility of introducing and forming a CMS in the organization with the definition of the CMF and to determine the conditions for integrating the CMS of the organization into the overall management system.

The article consists of an introduction, a literature review, research methods, results, discussion, and conclusion.

\section{Methods}

\section{Study design}

To prove the research hypothesis and achieve the set goals, a qualitative study of the functions of the CMS in the modern management of the organization was carried out. We used a complex of general and special scientific methods including:

- methods of comparison and generalization in the analysis of academic literature - to define the concept of "cost management";

- the expert survey method - to determine the main $\mathrm{CMF}$ and build a generalized CMF system of the organization and the conditions for integrating CMS of the organization into the general management system.

The main research method was the expert survey method. Experts in the field of financial accounting and control were invited to voluntarily answer the questions in a semi-formalized questionnaire.

Based on the method of an expert survey, CMFs and their elements and characteristics were determined. The feasibility of forming a CMS with the determination of a
CMF was substantiated, and the conditions for integrating the organization's CMS into the general management system are also defined.

\section{Procedure, research tools}

The survey involved 26 experts including specialists, employees of industrial companies, whose professional activities had been related to financial accounting and control for more than seven years.

All participants were informed about the purpose of the survey and the research organizers' plans to publish the summarized research results.

\section{Statistical analysis}

During the mathematical processing of the research results, the percentage of expert mentions of the CMS functions with their subsequent element-by-element characteristics was determined, as well as the percentage of expert mentions of the capabilities of the information base of costs and the condition of the organization's CMS integration into the general management system.

\section{Results}

The experts argued that to form an efficient CMS, one must focus on the functions that the system should perform (Table 2).

Table 2. Basic CMF

\begin{tabular}{|c|c|c|}
\hline No. & CMF & $\%$ \\
\hline 1 & Cost planning & $88.5 \%$ \\
\hline 2 & Organization of the cost management process & $84.6 \%$ \\
\hline 3 & $\begin{array}{c}\text { Communication between the hierarchical } \\
\text { levels of the CMS }\end{array}$ & $77.0 \%$ \\
\hline 4 & Cost control & $73.1 \%$ \\
\hline 5 & $\begin{array}{c}\text { Motivation for cost optimization at all levels } \\
\text { of bearing and managing the costs }\end{array}$ & $69.2 \%$ \\
\hline
\end{tabular}

Note: compiled based on the expert survey;* percent of references by the experts

The generalized system of CMFs is outlined in Table 3. 
Table 3. The generalized system of an organization's CMFs

\begin{tabular}{|c|c|c|}
\hline CMF & CMF element & CMF element features \\
\hline \multirow[b]{3}{*}{ Cost planning } & Strategic cost planning & $\begin{array}{l}\text { Involves forecasting costs based on standard cost indicators and a production } \\
\text { plan for finished products (goods, works, services) }\end{array}$ \\
\hline & Tactical cost planning & $\begin{array}{l}\text { Is based on a strategic plan considering the state of the internal and external } \\
\text { environment, market requirements, and probable risks }\end{array}$ \\
\hline & Operational cost planning & $\begin{array}{l}\text { Is calculated based on actual needs and production volumes for each of the areas } \\
\text { and workplace. Provides for the development of organizational and managerial } \\
\text { measures to adjust the production process by identifying and mobilizing } \\
\text { measures to optimize costs through improving manufacturing technology, } \\
\text { organizing supply logistics, organizing a closed production cycle, etc. }\end{array}$ \\
\hline \multirow[b]{2}{*}{$\begin{array}{c}\text { Organizing the cost } \\
\text { management process }\end{array}$} & Building an efficient CMS & $\begin{array}{l}\text { Is aimed at creating a system of actions focused on uniting all elements in } \\
\text { various areas of the enterprise's activities into a single spatiotemporal process, } \\
\text { forming a single information database, segmented by levels of access to } \\
\text { information on the corresponding hierarchical management levels }\end{array}$ \\
\hline & $\begin{array}{c}\text { Coordination of cost management } \\
\text { (development of logistical connections) }\end{array}$ & $\begin{array}{l}\text { The organization of the cost management process provides for the establishment } \\
\text { of costs centers and centers of responsibility for possible manifestations of } \\
\text { excess costs, losses with the determination of responsible persons, and the } \\
\text { boundaries of their responsibility area for each of the sections of the production } \\
\text { process }\end{array}$ \\
\hline \multirow[t]{2}{*}{$\begin{array}{l}\text { Communication } \\
\text { between the } \\
\text { hierarchical levels of } \\
\text { the CMS }\end{array}$} & Forming an informational database & $\begin{array}{l}\text { When organizing a production system, one must organize a system of } \\
\text { information resources for making efficient management decisions. This is } \\
\text { possible only with a single information database with differentiated hierarchical } \\
\text { levels of access. A system for coordinating the actions of executives by levels of } \\
\text { responsibility should be formed based on internal information links uniting all } \\
\text { levels of management. The development of a communication channel scheme } \\
\text { based on creating linear and nonlinear communication links }\end{array}$ \\
\hline & $\begin{array}{c}\begin{array}{c}\text { Continuous analysis of situations with } \\
\text { discrepancies between target indicators } \\
\text { and actual costs }\end{array} \\
\end{array}$ & $\begin{array}{l}\text { The formation of relevant information and its assessment over time makes it } \\
\text { possible to quickly respond to deviations from the target indicators and follow } \\
\text { the main goal of the organization }\end{array}$ \\
\hline \multirow[b]{2}{*}{ Cost control } & $\begin{array}{c}\begin{array}{c}\text { Reflection of the actual costs by a } \\
\text { certain level of detail }\end{array} \\
\end{array}$ & $\begin{array}{l}\text { Forms an information database on the actual state of costs incurred by cost items } \\
\text { and elements with the definition of centers of their responsibility }\end{array}$ \\
\hline & $\begin{array}{l}\text { Cost analysis by cost items and } \\
\text { elements with responsibility centers }\end{array}$ & $\begin{array}{l}\text { A constant comparative assessment between the actual incurred costs and their } \\
\text { planned value serves as the basis for making efficient, well-grounded } \\
\text { management decisions }\end{array}$ \\
\hline \multirow{2}{*}{$\begin{array}{c}\text { Motivation for cost } \\
\text { optimization at all } \\
\text { levels of bearing and } \\
\text { managing the costs }\end{array}$} & $\begin{array}{l}\text { Financial motivation for cost } \\
\text { optimization }\end{array}$ & $\begin{array}{l}\text { Financial motivation incentivizes workers to look for the most feasible methods } \\
\text { for optimizing costs and achieving the goals of the enterprise }\end{array}$ \\
\hline & $\begin{array}{c}\text { Moral and ethical incentives for cost } \\
\text { optimization }\end{array}$ & $\begin{array}{l}\text { Through moral and ethical incentives, managers influence the employees } \\
\text { performance and efficiency, encourage them to realize the main strategy of the } \\
\text { enterprise and make management decisions based on certain principles of the } \\
\text { enterprise }\end{array}$ \\
\hline
\end{tabular}

Note: compiled based on the expert survey.

\section{Discussion}

A CMS is a set of actions focused on achieving goals, not aimed $t$ reducing but at optimizing costs.

In the process of forming a CMS, it is important to reasonably define the main goal of the process. Since each company was created to make a profit, the level of profitability is an important indicator that management actions are aimed at. Management actions towards cost optimization to increase the level of profitability of the enterprise are focused on using material, labor, and financial resources more efficiently.

For this purpose, an enterprise should implement a planning (forecasting) enterprise cost mechanism, which will make it possible to develop economic measures focused on the long term.

The most accurate calculation and determination of all influencing costs factors with the development of alternative actions in the event of changes in the conditions of the enterprise's functioning affecting the result can be done using a general automated control system based on the use of information databases and modern software.

The experts believed that during the development of a general management system that will feature the CMS, the work of all structural departments at the enterprise should be coordinated with the development of strong horizontal and vertical logistics ties with the establishment of responsibility centers. The presence of a well-developed communication scheme for information transfer and interaction between structural divisions of the organization determines the efficiency of the management and control systems.

Due to such connections, the following processes are optimized:

- the level of detail of information on costs in the accounting system and indicators for calculating the product cost; 
- the ratio between the income and the costs incurred;

- the relationship between the results of activities and the actions of the persons responsible for the processes;

- the ratio between the efficiency of the costs incurred and the accuracy of calculations in the process of planning resource requirements, etc.

To optimize costs, one must establish responsibility for the use of resources for each workplace. For this purpose, it is advisable to keep records of costs based on technological processes and plan the costs based on clearly developed standards. Only with such a system of organizing cost management will there be an efficient control system based on planned indicators and data on actual costs incurred by types of resources and based on the volume of items produced.

The structure of the control system should have a hierarchical vertically integrated scheme, where each of the levels is controlled: from a production site, workshop or branch, to an enterprise or association [21].

Responsibility centers should be monitored according to a certain list of items that are indicated in the corresponding estimates or budgets. Estimates for hierarchical levels of responsibility form the overall summary budget for the enterprise. Therefore, an activity-based analysis of costs helps to manage the cost more efficiently, looking for reserves for their optimization [22].

A CMS built according to this scheme forms an information database in such a way that the employees who are authorized to make operational management decisions focus actions on achieving the strategic goal of the enterprise and contribute to the production of competitive products (goods, works, services). Since, having complete information about the actual state and target (planned) indicators of costs for each of the responsibility centers and the process, it becomes possible to react in time to probable deviations, investigate them to identify the causes, and develop methods for their elimination.

The control function makes it possible to set the level of costs, compare their actual value with target indicators, and identify the reasons for their incurrence, indicating those at fault. Efficient management decisions in the area of costs involve the choice of the most appropriate solution to the problem among the existing alternatives, which is focused on the stable development of the organization, and not only on obtaining the economic effect over a particular period [23].

According to the experts, among the CMFs of an enterprise, in addition to the functions of planning, organization, and control, the state of the internal communication system between the structural units of the enterprise (that is, internal logistical connections) and the implementation of the function of motivating employees are important.

The enterprise's executives need to understand that the implementation of the cost control function is possible only with an efficient system for cost analysis. Continuous in-depth analysis of the state and structure of costs by elements and cost centers provides the management of the corresponding hierarchical level with up-to-date information on the efficiency of using the existing resources of the organization, both as a whole and for individual processes [24]. Such an information database, according to the experts, offers the following features (Table 4).

Organized in this way, the CMS will provide for the development of actions focused on optimizing the costs both for individual processes and for the enterprise as a whole. The construction of a production process will be organized in the form of a closed cycle and focused on a stable gradual distribution of costs according to calculated indicators of the need for them according to the technological process.

Table 4. Features of the cost information database

\begin{tabular}{|c|c|c|}
\hline No. & \multicolumn{1}{|c|}{ Features of the cost information database } & $\%$ \\
\hline 1 & Identifying reserves for reducing the cost of products, goods, works, or services by operations & $80.8 \%$ \\
\hline 2 & Formation of a vision of the actions of each employee towards the efficient use of resources & $73.1 \%$ \\
\hline 3 & $\begin{array}{l}\text { Development of corrective actions focused on making efficient management decisions to optimize costs for each } \\
\text { stage of the life cycle of production (provision of services), from the stage of acquiring means of production to the } \\
\text { organization of the actual production process and sale of finished products, goods, or works }\end{array}$ & $65.4 \%$ \\
\hline 4 & Unification of all elements of the production chain closely related to each other into the process of a control system & $61.5 \%$ \\
\hline
\end{tabular}

Note: compiled based on the expert survey; * percent of references by the experts 
CMS at an enterprise organized based on clearly calculated needs will ensure the highest possible indicators of financial stability and will help to improve the level of the organization's profitability [25].

The experts clarified that, while integrating the organization's CMS into the general management system, one must meet the following conditions (Table 5).

At the executive level of the hierarchical structure of the enterprise in the process of implementing the CMF, it is important to ensure strong connections between the elements of the management system and build a mechanism for mutual cost regulation at the stages of planning, organization, development of the technological process, production, that is, in the process of building the entire economic mechanism of activity [26].

All this becomes possible only with an automated control system, which operates based on an information database. It is a source of information for the work of the analysis system for each operation that occurs in the organization and the basis for the operation of algorithms for making management decisions [27].

According to an expert, "with the emergence of groundbreaking innovations such as robotic process automation and cognitive technologies, cost management is now becoming a strategic tool that can revolutionize the way we do business".

According to the results of the Deloitte biennial global cost management survey report [28], cost reduction is currently a global imperative. The report that features insights from over 1,000 senior executives offers a conclusion that cost reduction has become a standard business practice in all regions surveyed (the USA, Latin America, Europe, and Asia-Pacific), with $86 \%$ of global respondents saying their companies are likely to undertake cost reduction initiatives over the next 24 months. At the same time, nearly half of all organizations surveyed are pursuing cost reduction targets of less than $10 \%$. Yet, despite relatively low targets, almost two-thirds $(63 \%)$ are failing to achieve their goals. Worldwide, the top external risk for organizations surveyed is "macroeconomic concerns/recession" (30\%), followed by "commodity price fluctuation" (19\%). Simultaneously, companies in all regions have been actively developing and improving their cost management capabilities. The top three focus areas are: "forecasting, budgeting, and reporting" (55\%); "new policies and procedures" (51\%), and "IT infrastructure, IT systems, and business intelligence platforms" (49\%). Many companies surveyed continue to focus on tactical cost actions (40\%), such as streamlining business processes and reducing external spend, versus strategic cost actions (33\%), such as outsourcing, centralization, and business reconfiguration. This tactical focus tends to limit the magnitude of cost savings that can be achieved.

Table 5. Conditions for integrating the organization's CMS into the general management system

\begin{tabular}{|c|l|c|}
\hline No. & \multicolumn{1}{|c|}{ Conditions for integration } & $\%$ \\
\hline 1 & $\begin{array}{l}\text { Development of actions focused on cost optimization at each stage of the production process, which will help to } \\
\text { maximize profit }\end{array}$ & $84.6 \%$ \\
\hline 2 & $\begin{array}{l}\text { Implementation of the function of planning and forecasting costs for each stage of production, based on the data of an } \\
\text { automated information database on cost centers and their standard and target indicators, calculated based on } \\
\text { production process sheets which will provide an efficient control system for their value }\end{array}$ & $80.8 \%$ \\
\hline 3 & $\begin{array}{l}\text { Adaptation of modern approaches to the CMS focused on the automation of both production processes and the } \\
\text { processes of forming a management system (organization, planning, budgeting, analysis, etc.), which will maximize } \\
\text { the economic effect }\end{array}$ & $77.0 \%$ \\
\hline 4 & $\begin{array}{l}\text { Development of methods for motivating personnel for the optimal use of resources in places of their origin, which } \\
\text { will contribute to obtaining a positive economic effect for the organization and improving the quality indicators of } \\
\text { the goods, works, or services produced }\end{array}$ & $73.1 \%$ \\
\hline 5 & $\begin{array}{l}\text { Formation of an automated control system for the costs incurred by comparing target and actual values, which will } \\
\text { make it possible to quickly identify the outlying indicators and find out the reasons for their occurrence }\end{array}$ & $73.1 \%$ \\
\hline 5 & $\begin{array}{l}\text { Accounting reflection of identifying costs and their values both by elements and by cost items in the context of } \\
\text { responsibility centers, which will provide executives with information resources for making efficient management } \\
\text { decisions }\end{array}$ & $69.2 \%$ \\
\hline 6 & $\begin{array}{l}\text { Formation of an efficient control system based on information received from the cost accounting system, which will } \\
\text { make it possible to identify deviations from planned and forecast indicators within the formed cost budgets for } \\
\text { production cycles and operations and will contribute to the development of the most efficient measures and actions } \\
\text { aimed at cost optimization }\end{array}$ & $65.4 \%$ \\
\hline 7 & $\begin{array}{l}\text { Development of the most efficient actions towards improving the production system, technological processes, } \\
\text { accounting, and control based on relevant cost data, which will ensure the implementation of the principle of } \\
\text { continuous improvement }\end{array}$ & $57.7 \%$ \\
\hline
\end{tabular}

Note: compiled based on the expert survey; * percent of references by the experts 


\section{Conclusions}

In conclusion, the following can be inferred.

1. Costs in the management system are an object that directly impacts the economic efficiency of the enterprise, the pricing mechanism in the production process, and, as a result, the state of competitiveness in the market.

2. To efficiently operate the enterprise and make informed management decisions, one must implement cost management through a planning system. We believe that one should organize cost management at all stages of the planning process and the production process. Cost management involves the development of a system of constant targeted impact on the structure of costs and their composition and behavior.

3. The process of cost optimization at an enterprise is carried out continuously at all hierarchical levels and stages of production, from the process of planning activities and organizing accounting records to monitoring the efficiency of bearing the costs. With the application of automation and information systems in the process of analyzing the database on the actual results of the enterprise's activities and the state of assets, liabilities, and capital, management decision-making is balanced and economically justified.

4. The developed information database of the structure and cost system of the enterprise determines the procedure for collecting operational information, its processing, and the analysis methodology with the subsequent application by the management level of the organization. This serves as a guarantee of the efficiency of making management decisions based on an analytical assessment of the organization's costs. Therefore, it is necessary to determine the main functions of the CMS in the modern enterprise management system.

5. As a result, it is possible to implement certain functions of the CMS only if an automated CMS is introduced and integrated into the general management system of the organization, which may become a prospect for further research.

\section{REFERENCES}

[1] M. Schoute. The relationship between cost system complexity, purposes of use, and cost system effectiveness, The British Accounting Review, Vol.41, No.4, 208-226, 2009.

[2] L. B. Akeem. Effect of Cost Control and Cost Reduction Techniques in Organizational Performance, International Business and Management, Vol.14, No.3, 19-26, 2017.
[3] S. Cohen, E. Kaimenaki. Cost accounting systems structure and information quality properties: an empirical analysis, Journal of Applied Accounting Research, Vol.12, No.1, $5-25,2011$.

[4] G. Cokins. Integrating target costing and ABC, Journal of Cost Management, Vol.16, No.4, 13-22, 2002.

[5] S. Apak, M. Erol, İ. Elagöz, M. Atmaca. The Use of Contemporary Developments in Cost Accounting in Strategic Cost Management, Procedia - Social and Behavioral Sciences, Vol.41, 528-534, 2012.

[6] K. Yasukata, E. Yoshida, I. Yamada, K. Oura. A longitudinal case study of target cost management implementation at a shipbuilding company, Journal of Accounting \& Organizational Change, Vol.9, No.4, 448-470, 2013.

[7] C.J. McNair. Beyond the Boundaries: Future Trends in Cost Management, Journal of Cost Management, Vol.21, No.1, 10-21, 2007.

[8] S. H. Hsu, S. Q. Qu. Strategic cost management and institutional changes in hospitals, European Accounting Review, Vol.21, No.3, 499-531, 2012.

[9] H. Shah, A. Malik, M. S. Malik. Strategic Management accounting - a messiah for management accounting?, Australian Journal of Business and Management Research, 2011. Vol.1, No.4, 1-7, 2011.

[10] B. Savic, Z. Vasiljevic, D. Djordjevic. Strategic cost management as instrument for improving competitiveness of agribusiness complex, Ekonomika Poljoprivrede, Vol.61, No.4, 1005-1020, 2014.

[11] D. C. Collatto, M. A. de Souza, A. P. do Nascimento, D. P. Lacerda, Interactions, convergences and interrelationships between Lean Accounting and Strategic Cost Management: a study in the Lean Production context, Gestão \& Produção, Vol.23, No.4, 815-827, 2016.

[12] S. B. Suloeva, O.B. Gultseva. Sistema upravleniya zatratami: kontseptualnyye polozheniya [Cost management system: conceptual provisions], Organizator proizvodstva, Vol.25, No.3, 47-58, 2017.

[13] C. Ganapaian. Strategic cost management (SCM) - key for sustainable development in changing economic scenario an analysis, BIMS International Journal of Social Science Research, Vol. 1, No.2, 141-147, 2016.

[14] E. V. Zenina. Teoreticheskiye i metodologicheskiye osnovy strategicheskogo upravleniya zatratami: monografiya [Theoretical and methodological foundations of strategic cost management: monograph]. Bishkek: KRSU, 2014.

[15] R. Cooper, R. Slagmulder. Interorganizational cost management and relational context, Accounting, Organizations and Society, Vol.29, No.1, 1-26, 2004.

[16] G. Favato, R. Mills. Identifying best practices in cost management, Henley Manager Update, Vol.18, No.3, 43-52, 2007.

[17] S. Aluko, J. Mayhall, M. Wauquiez, A. Vercio. Strategic cost management, Financial Management, 34-35, 2010.

[18] R. L. Tichacek, Effective Cost Management. Back to Basics, Cost Engineering, Vol.48, No.3, 27-33, 2006. 
[19] Kumar. Strategic cost management - suggested framework for 21st Century, Journal of Business and Retail Management Research, Vol.5, No.2, 118-130, 2011.

[20] Garg, D. Ghosh, H. Halper. Best practices in management accounting, Journal of Cost Management, Vol.18, No.2, 21-25, 2004.

[21] S. Maiga, A. Nilsson, F. A. Jacobs, Assessing the interaction effect of cost control systems and information technology integration on manufacturing plant financial performance, The British Accounting Review, Vol.46, No.1, 77-90, 2014.

[22] J. A. Botín, M. A. Verara. A Cost Management Model for Economic Sustainability and Continuous Improvement of Mining Operations, Resources Policy, Vol.46, 212-218, 2015.

[23] D. Cagwin, M. Bouwman. The Association between activity-based costing and improvement in financial performance, Management Accounting Research, Vol.13, No.1, 1-39, 2002.
[24] J. F. Henri, O. Boiral, M. J. Roy. Strategic cost management and performance: The case of environmental costs, The British Accounting Review, Vol.48, No.2, 269-282, 2016.

[25] Y. Zengin, E. Ada. Cost management through product design: Target costing approach, International Journal of Production Research, Vol.48, No.19, 5593-5611, 2010.

[26] M. Stępień. Sustainability as a determinant of cost management in the accounts of a manufacturing industry, Global Journal of Environmental Science and Management, Vol.5, SI, 151-159,2019.

[27] N. Hamzah, F. Firmansyah. Minimum Wages, Relative Wages, and Productivity: An Empirical Analysis on Indonesia Food and Beverage Industry, Universal Journal of Accounting and Finance, Vol.9, No.1, 33-43, 2021. https://doi.org/10.13189/ujaf.2021.090104

[28] Deloitte, Thriving in uncertainty in the age of digital disruption, Deloitte's first biennial global cost survey report, 2017, Online available from https://www2.deloitte.com/co ntent/dam/Deloitte/us/Documents/process-and-operations/ us-consulting-global-cost-survey-2107.pdf 